\title{
THE DYNAMIC OF THE ENERGY METABOLISM OF THE CELLS OF WHITE RATS SKIN CONNECTIVE TISSUE UNDER CONDITIONS OF THE BURN INJURY AND HYPERGLYCEMIA
}

\author{
${ }^{1}$ Natrus L.V., ${ }^{\text {IVerko N.P., }}{ }^{1}$ Ryzhko I.N., ${ }^{2}$ Panova T.I., ${ }^{2}$ Osadchuk Yu.S. \\ ${ }^{I}$ Scientific research institute of experimental and clinical medicine O.O. Bogomolets National Medical \\ University, Kyiv, Ukraine \\ ${ }^{2}$ O.O. Bogomolets National Medical University, Kyiv, Ukraine \\ Lnatrus777@gmail.com
}

Relevance. Macrophages exist in the wound in several phenotypic states, and the effect of these cells on intercellular co-operation at each stage of tissue repair depends on their specific phenotype. Depending on the microenvironment, they can quickly change their functional phenotype from proinflammatory M1 to anti-inflammatory M2, and vice versa. However, the effect of the functional phenotype of macrophages on cellular metabolism is not unilateral, the change in the features of metabolism, especially energy, also significantly affects the phenotype of cells.

Objective. The aim of this work is to analyze the oxidoreductases activity of neutrophils, macrophages and fibroblasts in the connective tissue of the white rats skin under conditions of local thermal damage when there is a carbohydrate metabolism violation to predict the efficiency of the tissue regeneration during the repair process.

Material and methods. There were carried out the histochemical and pathomorphological researches of the skin burn wound healing dynamic $(3,7,14,21$ days) of the white mature male rats (Wistar line) with the weight of $180-210 \mathrm{~g}$ without somatic pathology (control group, $\mathrm{n}=28$ ) and with stable uncorrected hyperglycemia modeled by streptozotocin $(\mathrm{n}=28)$. It has been carried out the histochemical study of oxidoreductase enzymes activity on the cryostat sections (10 $\mathrm{mm}$ thickness): succinate dehydrogenase (SDH), lactate dehydrogenase (LDH), NADH- dehydrogenase (NADH-DH). The histochemical index of the oxidoreductase enzymes activity was being calculated by the semi-quantitative method.

Results. The study of the cells' quantitative changes in the connective tissue regenerate and the reactions of energy metabolism against the background of hyperglycemia has some features. The consistency of the connective tissue infiltration by the leukocytes of different types during reparative regeneration after burn injury was being happened in a classical scenario with a quantitative predominance of cells in a group of animals without somatic pathology that points to the reduction of blood reactivity under conditions of glycemia. In the dynamics of the healing process the change of the LDH and NADH-DH activity in the macrophages and fibroblasts had a tendency to increase on the 7th and 14th days of the experiment and differed significantly during observation from the parameters in the $3 \mathrm{~d}$ day $(\mathrm{p}<0,05)$. The most exemplary for study of the dynamics of the oxidation-reduction enzymes activity in the cells of the regenerate was the ratio of SDH/LDH. Comparing the data of the control group of animals and under conditions of hyperglycemia the most expressed and multidirectional changes of the oxidation-reduction enzymes' activity occurred in macrophages in the different phases of the reparative process.

Conclusions. We believe that such differences can indirectly indicate the untimely change of the macrophages' functional phenotype during restorative processes in the tissues. So as the macrophages are the "main conductor" of intercellular relationships it is suggested that this mechanism may be one of the reasons for the ineffective wound healing under diabetes mellitus.

Key words: cells reactions of connective tissue, burn injury, stable uncorrected hyperglycemia, phenotype of macrophages, enzymes of tissue oxidation.

Relevance. Normally the wound process occurs in three phases: inflammation, proliferation-epithelization (formation of the granulation tissue), contraction (remodeling) [17]. The first polymorphonuclear leukocytes appear in the wound in a few minutes after injury peaking in 24-48 hours and then their number is gradually decreased but even in the later stages of the healing they are found in the inflammatory infiltrate (Fig. 1). The both leukocytes and inflammatory mediators activate the complement system, interact with kallikrein-kinin system, blood coagulation and fibrinolysis systems $[1,5,8]$. A partial lysis of the blood clot, foreign bodies, bacterial microflora occurs with the participation of neutrophils and proteolytic enzymes of macrophages. The monocytes/macrophages interact with the intercellular matrix and other cell populations by the mediators $[8,17,21]$. Through the integrin receptors the macrophages bind to extracellular matrix components activating phagocytosis $[1,9]$. In 2 days after the injury under the growth factors influence the epithelial cells located at the wound edges begin to actively proliferate, migrate, fix on the newly formed basal membrane forming normal structural bonds with it and the dermis. At the same time the process of degradation and remodeling of the extracellular matrix takes place that facilitates re-epithelialization and plays 
a key role in the transition process from the granulation tissue into a scar [13]. The complex interaction of different cells, mediators and extracellular matrix components leads to wound contraction. The fibroblasts acquire a phenotype of myofibroblasts from the 7 th to the 14 th day of the wound process that indicates the formation of the full connective tissue [3].

Many studies showed that tissue-resident macrophages play a key role in the tissue repair $[1,4$, $21]$. In the wound the macrophages are present in the different functional phenotypes that determine their participation in the intercellular cooperation of each stage of the tissue repair. Among cells of the immune system the macrophages are the most plastic [18]. Depending on the microenvironment they can quickly change their functional phenotype from the proinflammatory (M1) to the anti-inflammatory (M2) and vice versa that is the macrophages reprogramming $[9,20,21]$. The phenomenon of the macrophages reprogramming determines the efficiency of the regeneration process of the damaged tissues. For example the anti-inflammatory phenotype of the macrophages promotes a complete restoration of the structure and function of the damaged tissue. On the contrary the macrophages with the proinflammatory phenotypes through the production of TGF repress the realization of a full regeneration effect in the tissues resulting in a scarring and fibrosis (Figure 2) [21]. Hyperglycemia leads to proteins glycation including hemoglobin, collagen that stimulates fibrogenesis $[6,7$, 12]. The reprogramming of macrophages leads to both a change of the functional properties and metabolism of these cells. On the other hand a change of the macrophages metabolism, first of all energy, significantly affects the phenotype of these cells too [6].

The aim of this work is to analyze the oxidoreductases activity of neutrophils, macrophages and fibroblasts in the connective tissue of the white rats skin under conditions of local thermal damage when there is a carbohydrate metabolism violation to predict the efficiency of the tissue regeneration during the repair process.

\section{MATERIAL AND METHODS}

There were carried out the histochemical and pathomorphological researches of the skin burn wound healing dynamics of the white mature male rats (Wistar line) with the weight of $180-210 \mathrm{~g}$ without somatic pathology (control group, $n=28$ ) and with stable uncorrected hyperglycemia $(\mathrm{n}=28)$.

The model of the stable uncorrected hyperglycemia was reproduced by the intraperitoneal injection of streptozotocin into rats once $(50 \mathrm{mg} / \mathrm{kg})$ that was previously dissolved in $0,1 \mathrm{M}$ citrate buffer $(\mathrm{pH} 4.5)$. An experiment duration was 1 month. As a control of the hyperglycemia development there was the blood

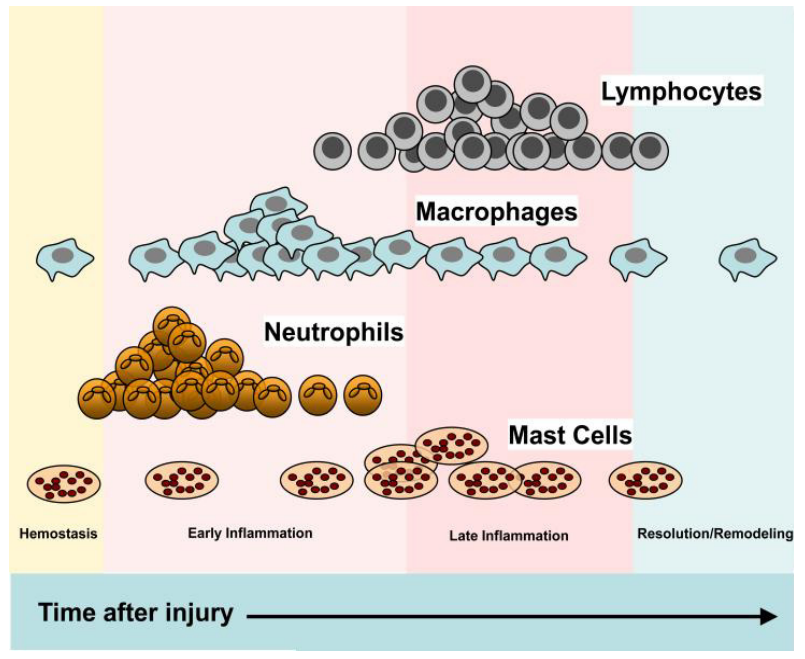

Fig.1. The pattern of leukocyte infiltration into wound (Koh and DiPietro, 2013 [9]).

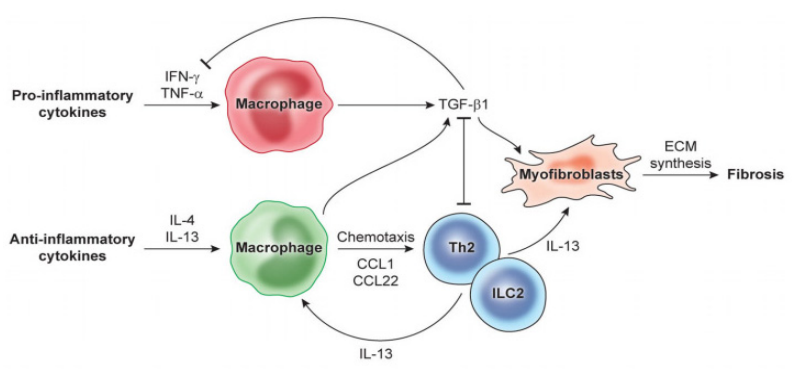

Fig. 2. Interaction of the different macrophages phenotypes with the lymphocytes through the cytokines and macrophages mediators in the implementation of the fibrosis mechanism (Wynn and Vannella, 2016, [21]).

glucose level $-24,24 \pm 0,79 \mathrm{mmol} / 1$, in the control group $8,03 \pm 0,4 \mathrm{mmol} / \mathrm{l}$.

For experimental modeling of the burn on the eve the rectangular area of the rats trunk skin was exposed to simulate a burn under the ketamine anesthesia (75 $\mathrm{mg} / \mathrm{kg}$ ) [10]. Two copper plates with the ellipse form were held at $100^{\circ} \mathrm{C}$ for $10 \mathrm{~min}$ and placed simultaneously symmetrically on the both exposed parts of the rats body with an exposure time of $10 \mathrm{~s}$. The total area of skin burn was $18-20 \%$ of the body surface that is quite sufficient for the formation of the second-degree burns (according to the old classification there is the third A degree). On the $3 \mathrm{~d}, 7 \mathrm{th}, 14 \mathrm{th}, 21 \mathrm{st}$ days the rats were intraperitoneal administered once a lethal dose of thiopental sodium and removed from the experiment by the decapitation.

For the pathomorphological and histochemical studies the skin flaps were taken from the lateral parts of the body. The conventional methods of the pathomorphological analysis were used. The material was fixed in $10 \%$ neutral formalin, conducted through a battery of alcohols with an ascending concentration 
(70, 80, 96I, 96II, 96II, 100), alcohol-chloroform, chloroform, chloroform-paraffin (at $37^{\circ} \mathrm{C}$ ), paraffin (at $57^{\circ} \mathrm{C}$ ) and poured in paraffin wax. The serial paraffin sections (7 Mm thickness) were stained with hematoxylin and eosin, and van Gieson staining. The content of fibroblasts, macrophages and neutrophils (arbitrary units) was calculated on an area of 130x130 Mm of the histological section where each cell type was counted in 20 fields of the vision followed by dividing the number of each cell type by the number of vision fields.

The histochemical studies of the oxidoreductases activity were carried out by the cryostat sections (10 Mm), namely, succinate dehydrogenase, SDH (by the method of Nachlas et al., 1957), lactate dehydrogenase, LDH (by the method of Hess, Scarpelli and Pierce, 1960), NADHdehydrogenases, NADH-DH (by the method of Farber et al., 1956) - based on registration of the diformasan granules that are formed during the reduction of tetrazolium salts. The histochemical index of oxidoreductases activity was calculated by the semiquantitative method according to the principle of Astaldi (Astaldi et al., 1965) based on detection of the specific staining of the different intensity of the final product of reaction (diformasan) in the 100 cells cytoplasm of a certain type. The staining intensity was assessed as: weakly positive reaction $(+)$, positive reaction $(++)$, sharply positive reaction $(+++)$. The average histochemical index $(\mathrm{AHI})$ of enzyme activity (arbitrary units) was calculated by the Kaplow formula (1979) modified by Astaldi and Verga: $\mathrm{AHI}=(1 \mathrm{a}+2 \mathrm{~b}+3 \mathrm{c}) / 100$, where the numbers $(1,2,3)$ are staining intensity; letters $(a, b, c)$ are amount of counted cells with a certain staining intensity.

The data analysis was performed by the variational statistics methods using the t Student's test. If the pvalue was less than 0,05 the results were considered statistically significant.

\section{RESULTS AND DISCUSSIONS}

The results of our previous studies [10] showed that animals of all groups in the first 3 days after burn had necrotic changes in the epidermis, hair follicles, dermis edema. The stasis and thrombosis were developed in the vessels of hemomicrocyrculatory channel. In the control group of the animals the burn wound infliction has led to the development of a young granulation tissue rich in neutrophilic granulocytes at the bottom of the wound during the first 3 days of the observation. In 3 days of the experiment a large number of the cellular elements has accumulated in the edges and bottom of the wound that form a full granulation tissue by the 7 th day. On the 14th day of observation there was a significant amount of collagen fibers the density of which has increased from the surface to the deep layers. The regeneration of the epidermis occured simultaneously with the connective tissue regeneration. The assessment of migratory processes into connective tissue of the skin (Fig. 3, a) revealed the maximum content of the neutrophils on the $3 \mathrm{~d}$ day $(68,8 \pm 3,0)$ with a gradual decrease to $55,4 \pm 3,6(\mathrm{p}<0,05)$ by the 7 th day, to $30,0 \pm 2,5(\mathrm{p}<0,05)$ by the 14 th day and on the 21 st day $12,8 \pm 0,3(\mathrm{p}<0,05)$. The migration of the macrophages into wound tissue had a different dynamics (Fig. 3, b). On the 3d day of observation the content of the cells was $66,5 \pm 2,5$ then it has reached the maximum value in the tissue $(68,5 \pm 2,8)$ by the 7 th day decreasing to $51,2 \pm 1,7$ by the 14 th day and to $16,9 \pm 0,3$ by the 21 st day $(\mathrm{p}<0,05)$. There was maximal content of fibroblasts $(60,2 \pm 2,8)$ in the connective tissue of control group animals on the 7 th day of wound process current (Fig. 3, c) that is greater 3,6 times than at the beginning of regeneration on the $3 \mathrm{~d}$ day of experiment. On the 14th and 21 st days of the observation the content of fibroblasts in the regenerate connective tissue has decreased to $53,5 \pm 1,7$ and to $34,7 \pm 1,4(\mathrm{p}<0,05)$ respectively.

Thus during the entire period of wound healing the content of the neutrophils has gradually decreased in the newly formed connective tissue but content of the macrophages and fibroblasts has increased by the 7 th day decreasing in the following days of observation in the control group of animals.
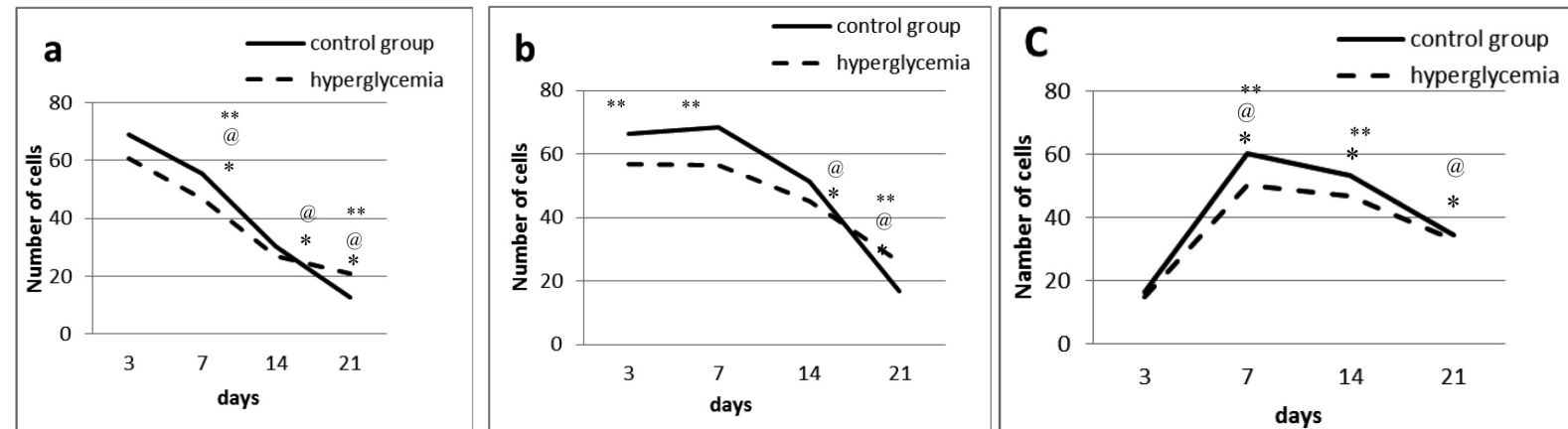

Fig. 3. Content of neutrophilic granulocytes (a), macrophages (b) and fibroblasts (c) (arbitrary units) in the connective tissue regenerate of the derma during the dynamics of the burn wound skin in the rats without somatic pathology - control group (solid line) and with a model of the stable uncorrected hyperglycemia (dotted line), $(\mathrm{M} \pm \mathrm{m} ; \mathrm{p}) .{ }^{*}-\mathrm{p}<0,05$ in the dynamics of observation in the control group of rats, @ - $p<0,05$ in the dynamics of the observation in the group of rats with hyperglycemia, ** $-\mathrm{p}<0,05$ in comparison between groups of rats. 
Natrus L.V., Verko N.P., Ryzhko I.N., Panova T.I., Osadchuk Yu.S.

The comparative analysis of the healing dynamics of the burn wound of the rats skin with a model of the stable uncorrected hyperglycemia in comparison with the control studies showed some features of the restoration of injured tissue. In the regenerate there are thin collagen fibers in a smaller amount than in the control group. The granulation tissue that was formed in the wound up to 7 th day of the experiment was thinner than in the control group of the animals, it contains less blood vessels (with a smaller diameter), fibroblasts, macrophages and neutrophils. The number of the neutrophils in the wound (Fig. 3, a) was less than in the control group on the $3 \mathrm{~d}$ day of the observation $(60,8 \pm 3,2)$ and gradually decreased to the 21 st day (the 7 th day $-46,7 \pm 2,4$; the 14 th day $-26,8 \pm 1,6$; the $21 \mathrm{st}$ day $-20,8 \pm 0,1, \mathrm{p}<0,05)$ ) but it remained 1,6 times more compared to the control group $(p<0,05)$ by the end of the experiment. Similar changes were observed in the dynamics of the macrophages content in the regenerate of the rats with the hyperglycaemia (the 7 th day $-56,6 \pm 2,3$; the 14 th day $-45,3 \pm 2,5$; and the $21 \mathrm{st}$ day $-26,0 \pm 0,3, \mathrm{p}<0,05$, Fig. $3, \mathrm{~b})$ but their number was more 1,4 times than in the control group by the end of the study. The dynamics of the fibroblasts content in the regenerate of the rats with the hyperglycemia (Fig. 3 , c) was similar to the control group. The differences between groups were significant $(p<0,05)$ on the 7 th and 14th days of the observation when the fibroblasts content reached a maximum value, namely, 50,4 $\pm 2,2$ and $46,7 \pm 1,8$ respectively compared with $15,0 \pm 0,5$ on the $3 \mathrm{~d}$ day. On the $21 \mathrm{st}$ day of observation the fibroblasts content decreased to a level of 33,0 $\pm 1,5$.

The preliminary histochemical study of the enzymes activity in the cellular elements (fibroblasts, macrophages, neutrophil granulocytes) of the granulation tissue [10] of the control group animals showed that AHI of SDH and NADH-DH activity had a tendency to reduce in all cellular elements but AHI of LDH and NADH-DH activity in macrophages and fibroblasts has increased on the 7 th and 14th days of the experiment and significantly differed from those in the $3 \mathrm{~d}$ day of the observation $(\mathrm{p}<0,05)$. When there was both burn wound of the skin and stable uncorrected hyperglycemia a number of diformasan granules in the cytoplasm of fibroblasts, neutrophils, macrophages has increased upon detection of activity of all oxidoreductases except of LDH whose AHI of enzyme activity had a tendency to decrease in neutrophils. In the dynamics of changes of AHI of enzyme activity the statistically significant differences $(p<0,05)$ were registered only for $\mathrm{LDH}$ and $\mathrm{NADH}-\mathrm{DH}$ in the macrophages and fibroblasts of rats skin regenerate with the stable uncorrected hyperglycemia.

Thus the results of oxidoreductases activity in the cells of regenerate of both experimental groups animals showed mainly a slight variation of these parameters and taking into account the method of enzymatic activity evaluation we can interpret the absolute data as a tendency to increase or decrease of enzyme activity in the dynamics of observation. Therefore we analyzed the ratio of $\mathrm{AHI}$ of SDH and LDH activity (SDH/LDH) in the cells of connective tissue regenerate in dynamics (Fig. 4).

Almost all values of $\mathrm{SDH} / \mathrm{LDH}$ ratio were $<1$ that can indicate the predominance of glycolytic pathway energy synthesis. According to the literature the transition to a fast way of energy obtaining - anaerobic oxidation with accumulation of lactate - is inherent in actively proliferating cells and it takes place during the reparative regeneration $[2,15,19]$. The oxygen deficiency in the tissues causes the accumulation of pyruvate and nicotinamide coenzymes in the cells that are converted into lactate and NAD under the action of the LDH [19].

The comparative analysis (Fig. 4, a) showed that in the group of the animals with hyperglycaemia the value of $\mathrm{SDH} / \mathrm{LDH}$ ratio in the neutrophils was lower the same parameter in the group of the animals without somatic pathology during all periods of the observation. In the macrophages of connective tissue regenerate of the animals group without somatic pathology (Fig. 4, b) the value of SDH/LDH had a relatively constant level during the period of 3-7 days of the observation. On the14th day the value of this parameter has changed due to an increase of SDH activity followed by reduction of SDH/LDH value by the 21 st day of the experiment. Considering the fact that the macrophages are present in the tissue for 20-21 days and this time we have found the decrease of the macrophages content in the regenerate, it is likely, such an oscillation of oxidoreductases activity there is a feature of repair processes optimization. On the background of hyperglycemia there was other dynamics of the changes of SDH/LDH value in the macrophages. Unlike the control group of the study the $\mathrm{SDH} / \mathrm{LDH}$ ratio had a minimal value on the 14 th day $(\mathrm{p}<0,05)$ with a subsequent increase to 1 by the $21 \mathrm{st}$ day that indicates the same activity of enzymes in the regenerate of this observation period. In the fibroblasts of the skin regenerate of the animals without somatic pathology the value of $\mathrm{SDH} / \mathrm{LDH}$ was maximally reduced by the 7 th day and then it has gradually increased to $21 \mathrm{st}$ day. Against the background of hyperglycemia these processes were delayed in time, exactly, the minimal value of SDH/LDH was fixed on the 14th day.

Considering the fact that, firstly, we used the semiquantitative visual evaluation of enzyme activity and, secondly, LDH is only one of the enzymes that is activated during the substrate level phosphorylation in the cytoplasm of the cells in the first stage of the glucose oxidation [11]. Therefore we can only assume or lactate will be accumulated in the cell under conditions of the hypoxia deepening either cell will 
a

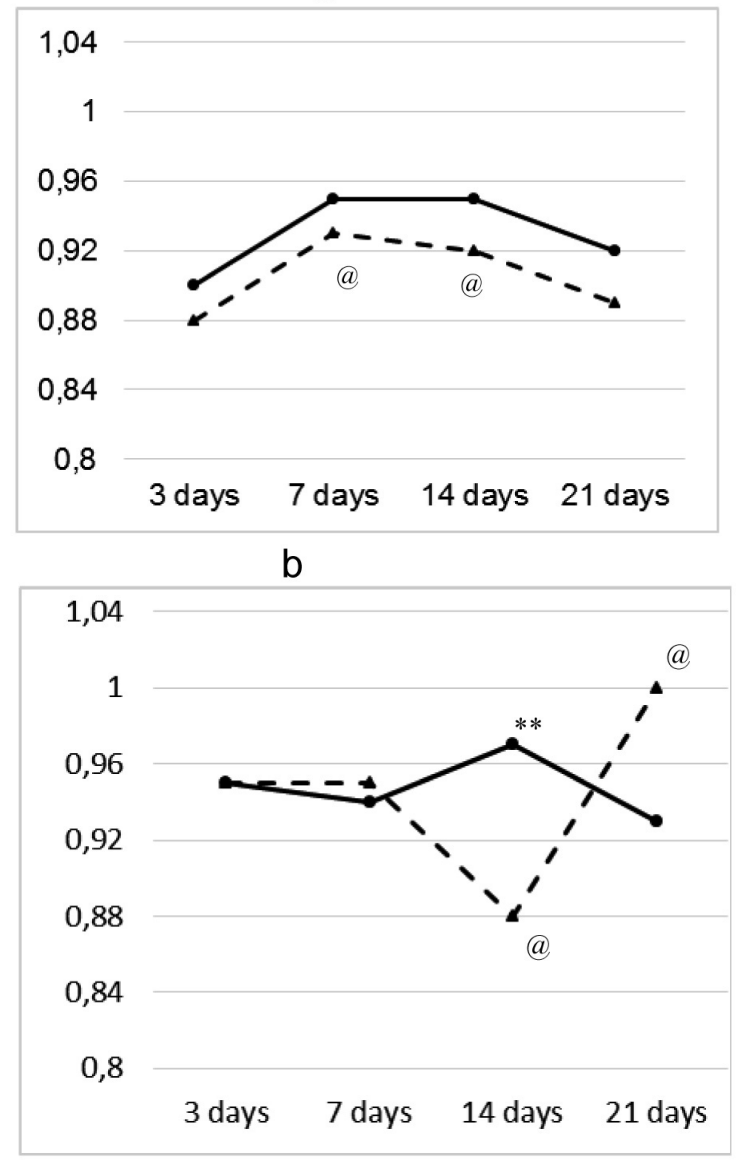

C

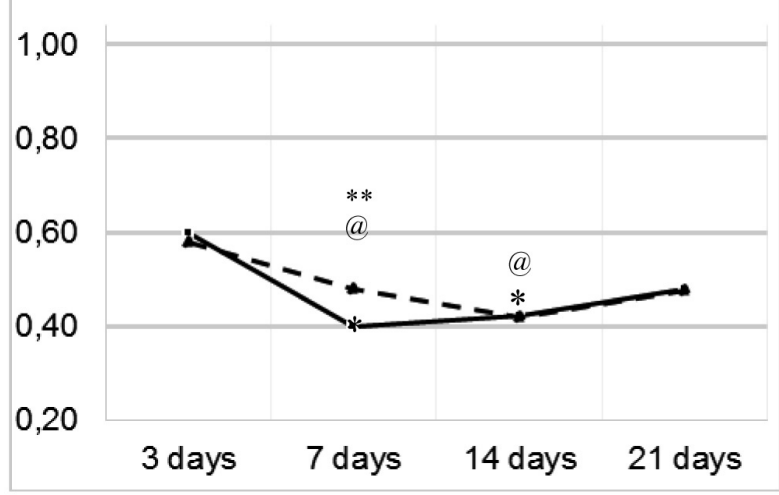

Fig.4. The value of SDH/LDH ratio in the neutrophilic granulocytes (a), macrophages (b), fibroblasts (c) of the connective tissue regenerate during the wound healing in the rats without somatic pathology (solid line) and with a model of the stable uncorrected hyperglycemia (dotted line) $(\mathrm{M} \pm \mathrm{m} ; \mathrm{p})$. Notation as Fig. 3.

continue the way of ATP synthesis in the cycle of tricarboxylic acids under conditions of intake of sufficient oxygen that will be reflected by the increase of SDH activity - mitochondrial oxidation enzyme. However we believe that such an oscillation of SDH/ LDH ratio in the regenerate cells of the control group and the animals with the stable uncorrected hyperglycemia in the dynamics of wound healing allows us to think about the features of the functional transformation of cells in the wound especially the change in the macrophages phenotype.

Based on the literature data we believe that the results of the study of the macrophage enzymes activity can reflect the changes of their energy metabolism associated with a change in the phenotype of these cells during the wound healing. Nowdays the functional plasticity of macrophages is actively discussed depending on the changes in the environment they are located. In the activated proinflammatory macrophages (M1 phenotype) the expression of the NO synthase is increased in the response to hypoxia. This enzyme catalyzes the formation of the nitric oxide (NO) from L-arginine [12, 13]. We assume that M1 macrophages prevail in the wound for 3-7 days so as the formation of the M1 phenotype is accompanied by the increase in NO production that enhances the contribution of glycolysis to ATP production [12].

On the 14th day of the wound process the value of $\mathrm{SDH} / \mathrm{LDH}$ varied due to an increase of SDH activity, compared to the 7th day, that can indicate the activation of aerobic process. According to our point of view this period is characterized by the cells differentiation and the conversion of the macrophages phenotype from the M1 to the M2. This is known that the creation of the anti-inflammatory macrophages pool (M2 phenotype), that takes part in the formation of myofibroblasts and effective tissue regeneration, is accompanied by the shift in the arginine metabolism towards to activation of arginase- 1 and the increase of ATP synthesis due to mitochondrial oxidation $[12,13$, $16]$. On the 21 st day of the wound process monitoring the both content of macrophages in the regenerate and oxidoreductases activity have decreased that probably testifies to reparation process optimization.

The dynamics of enzymes activity against the background of the stable uncorrected hyperglycemia had other scenario. There was significant prevalence of LDH activity in the macrophages on the 14th day that can indicate the predominance of anaerobic process of ATP synthesis over aerobic oxidation. We believe this can characterize the presence of active proliferation of M1 macrophages and their functional activation in the wound that can be considered as one of the cell's mechanisms of the wound healing inhibition.

On the 21 st day of the wound process against the background of prolonged hyperglycemia there was an increase of SDH activity in the macrophages to the level of LDH that reflects the activation of mitochondrial oxidation that is the change in the metabolic conditions of the tissue regenerate [14]. So as the change of the metabolism affects the reprogramming of the macrophages functional phenotype (conversion from the M1 to the M2 
phenotype) $[12,13]$ likely there will be predominance of M2 macrophages in the wound this time. It is known that the function of M2 macrophages is to remove the toxic products from the environment due to the action of their lytic enzymes. However the extra activity of metalloproteinases and other lytic enzymes of the macrophages on the products of the extracellular matrix is inexpedient in this stage that leads to chronic inflammation $[9,16,21]$.

Thus the results of the study of the oxidoreductases activity in the cells of the burn wound regenerate allows to assume that the change of the macrophages functional phenotype occurs not in time against the background of the hyperglycemia. So as macrophages play an important role in the intercellular interactions this mechanism can be one of the causes of the impaired wound healing in the diabetes mellitus. These assumptions require the detailed studies of the specific cells' markers and tissues cytokines as mediators of the interaction between cells that allows to get the confirmation of the hypothesis about possible cellular mechanism of the wound healing inhibition in the hyperglycemia.

\section{CONCLUSIONS}

The study of the quantitative changes of the cells in the connective tissue regenerate and also the enzymes activity of the energy metabolism in these cells against the background of hyperglycemia had certain features. The consistency of infiltration of the burn wound by the different types of leukocytes during the reparative regeneration occurred according to the classical scenario with a quantitative predominance of the cells in the group of animals without somatic pathology that indicates the decrease of the blood reactivity in the glycemia. In the dynamics of the enzymatic activity changes there was an increase of the both LDH and NADH-DH AHI in the macrophages and fibroblasts on the 7 th and 14 th days that significantly differed from those on the $3 d$ day of experiment $(p<0,05)$.

The most significant parameter for study of the dynamics of the oxidoreductases activity in the cells of the regenerate there was the $\mathrm{SDH} / \mathrm{LDH}$ ratio. The multidirectional changes of the SDH/LDH ratio took place in the macrophages of the regenerate of the both rats groups in the different phases of the repair process. We believe that such differences can indirectly indicate the changes in the functional phenotype of macrophages during the wound healing.

Further we believe it will be expedient to study the cell differentiation markers of the macrophages for a clear understanding of the intercellular interactions in the damage area against the background of the hyperglycemia as a mediator of the fibrogenic signaling pathways activation to clarify the pathogenesis of disturbed remodeling of the tissues and the ways of its elimination in the diabetes mellitus.
Конфлікт інтересів. Автори заявляють, що не мають конфлікту інтересів, який може сприйматися таким, що може завдати шкоди неупередженості статті.

Джерела фінансування. Ця стаття не отримала фінансової підтримки від державної, громадської або комерційної організацій.

\section{REFERENCES}

1. Anghelina M., KrishnanP., Moldovan L. et al. Monocytes and macrophages form branched cell columns in matrigel: implications for a role in neovascularization // Stem Cells Dev. 2004. 13 (6). 665-676. doi: 10.1089/scd.2004.13.665

2. Chen L., Xu Y., Zhao J., et al. Conditioned medium from hypoxic bone marrow-derived mesenchymal stem cells enhances wound healing in mice // PLoS One. 2014.9 (4). 342-350. doi: 10.1371/journal.pone. 0096161. eCollection 2014.

3. Danilov R. Wound process: histogenetic basis. - St. Petersburg: named after Kirov VMedA., 2008. - 380 p. (in Russian).

4. Eming S., Martin P., Tomic-Canic M. Wound repair and regeneration: mechanisms, signaling, and translation // Sci Transl Med. 2014. 2 (6). 265-273. doi: 10.1126/scitranslmed.3009337.

5. Fadini G., Ferraro F., Quaini F., et al. Concise review: diabetes, the bone marrow niche, and impaired vascular regeneration // Stem Cells Transl Med. 2014. 3 (8). 949-957. doi: 10.5966/sctm.2014-0052.

6. Galvбn-Peca S, O’Neill L. Metabolic reprograming in macrophage polarization // Front Immunol. 2014. 2 (5). 420-425. doi: 10.3389/fimmu.2014.00420. eCollection 2014

7. Hu S. Lan C.High-glucose environment disturbs the physiologic functions of keratinocytes: Focusing on diabetic wound healing // J DermatolSci. 2016. 84 (2). 121-127. doi: 10.1016/j.jdermsci.2016.07.008.

8. Kasama T., Miwa Y., Isozaki T. et al. Neutrophilderived cytokines: potential therapeutic targets in inflammation // Curr Drug Targets Inflamm Allergy. 2005. 4 (3). 273-279.

9. Koh T, DiPietro L. Inflammation and wound healing: The role of the macrophage // Expert Rev Mol Med. 2013. 1-14. doi: 10.1017/S1462399411001943

10. Kolesova N., Natrus L., Litvinenko V. et al. Dynamic of connective-tissue cell reactions of the skin of white rats with burn injury and persistent uncorrected hyperglycemia // Medichna nauka Ukraini. 2016. 12 (3-4), 4-11(in Ukrainian).

11. Meshcheryakova O., Churova M., Nemova N. Mitokhondrial'nyy laktat-okislyayushchiy kompleks i yego znacheniye dlya podderzhaniya energeticheskogo gomeostaza kletok // Sovr.prob.fiziol. 2010. (1). 163-171 (in Russian).

12. Modolell M., Corraliza I., Link F., et al. Reciprocal regulation of the nitric oxide synthase/arginase balance in mouse bone marrow-derived macrophages 
by TH1 and TH2 cytokines // Eur J Immunol. 1995. 25 (4). 1101-1104.

13. Recalcati S., Locati M., Marini A., et al. Differential regulation of iron homeostasis during human macrophage polarized activation // Eur J Immunol. 2010. 40 (3). 824-835. doi: 10.1002/eji.200939889

14. Rodriguez P., Felix F., Woodley D., et al. The role of oxygen in wound healing: a review of the literature // Dermatol Surg. 2008. 34 (9). 1159-1169. doi: 10.1111/j.1524-4725.2008.34254.x.

15. Schreml S., Szeimies R., Prantl L., et al. Oxygen in acute and chronic wound healing // Br J Dermatol. 2010. 163 (2). 257-268. doi: 10.1111/j.13652133.2010.09804.x

16. Sharda D., Yu S., Ray M., al. Regulation of macrophage arginase expression and tumor growth by the Ron receptor tyrosinekinase // J Immunol. 2011. 187 (5). 2181-2192.

17. Shekhter A., Serov V. Inflammation, adaptive regeneration and dysregeneration (intercellular interaction analysis) // ArkhPatol. 1991. 53 (7). 7-14 ( in Russian).

18. Sindrilaru A., Peters T., Wieschalka S. et al. An unrestrained proinflammatory M1 macrophage population induced by iron impairs wound healing in humans and mice // J Clin Invest. 2011. 121 (3). 985997. doi: 10.1172/JCI44490.

19. Trabold O, Wagner S, Wicke C. et al. Lactate and oxygen constitute a fundamental regulatory mechanism in wound healing // Wound Repair Regen. 2003. 11 (6). 504-509.

20. Vogl T,Tenbrock K,Ludwig S, et al.Mrp8 and Mrp14 are endogenous activators of Toll-like receptor 4 , promoting lethal, endotoxin-induced shock // Nat Med. 2007. 13 (9). 1042-1049. doi: 10.1038/nm1638

21. Wynn T., Vannella K. Macrophages in tissue repair, regeneration, and fibrosis // Immunity. 2016. 44 (3). 450-462. doi: 10.1016/j.immuni.2016.02.015.

Отримано: 18.10 .2017

\title{
ДИНАМІЧНІ ЗМІНИ ЕНЕРГЕТИЧНОГО МЕТАБОЛІЗМУ КЛІТИН СПОЛУЧНОЇ ТКАНИНИ ШКІРИ БІЛИХ ЩУРІВ В УМОВАХ ОПІКОВОЇ ТРАВМИ ТА ГІПЕРГЛІКЕМІЇ
}

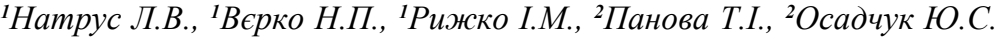 \\ ${ }^{1}$ Науково-дослідний інститут експериментальної та клінічної медицини НМУ імені О.О.Богомольия, Київ, \\ Україна \\ ${ }^{2}$ Національний медичий університет імені О.О.Богомольия, Київ, Украӥна
}

\begin{abstract}
Актуальність. Макрофаги існують у рані в декількох фенотипічних станах, і вплив цих клітин на міжклітинну кооперацію кожного етапу тканинної репарації залежить від їх конкретного фенотипу. Залежно від мікрооточення, вони можуть швидко змінювати свій функціональний фенотип з прозапального М1 на протизапальний М2, і навпаки. Однак вплив функціонального фенотипу макрофагів на клітинний метаболізм не є одностороннім, зміна особливостей метаболізму, перш за все енергетичного, також істотно впливає на фенотип клітин.

Метою роботи було проаналізувати активність окисно-відновних ферментів нейтрофілів, макрофагів і фібробластів сполучної тканини шкіри білих щурів, які приймають участь в процесах тканинного дихання за локального термічного ушкодження при порушенні вуглеводного обміну в експерименті для прогнозування ефективності тканинної регенерації в ході репараційного процесу.
\end{abstract}

Матеріали та методи. Проведені патоморфологічні та гістохімічні дослідження динаміки (3, 7, 14, 21 доба) гоєння опікової рани шкіри білих статевозрілих щурів-самців лінії Вістар масою 180-210 г без соматичної патології (контроль) (n=28) та за стійкої не корегованої стрептозотоцин-індукованої гіперглікемії (n=28). На кріостатних зрізах (10 мкм) проводили гістохімічне вивчення активності оксидоредуктаз: сукцинатдегідрогенази (СДГ), лактатдегідрогенази (ЛДГ), НАДН-дегідрогенази (НАДН-ДГ). Гістохімічний показник активності ферментів обчислювали напівкількісним методом.

Результати. Дослідження кількісних змін клітин у сполучнотканинному регенераті та реакцій енергетичного метаболізму на тлі гіперглікемії має ряд особливостей. Послідовність інфільтрації сполучної тканини різними видами лейкоцитів під час репаративної регенерації після термічної травми відбувалася за класичним сценарієм 3 кількісним переважанням клітин у групі тварин без соматичної патології, що вказує на зменшення реактивності крові за умов глікемії.

У динаміці перебігу загоєння зміна активності ЛДГ і НАДН-ДГ в макрофагах та фібробластах мала тенденцію до посилення на 7 та 14 добу експерименту і достовірно відрізнялась у ході спостереження від показників на 3 добу (р <0,05).

Найбільш показовим для вивчення динаміки активності окисно-відновних ферментів в клітинах регенерату виявилося співвідношення СДГ/ЛДГ. У порівнянні даних контрольної групи тварин та за умов гіперглікемії найбільш виражені і різноспрямовані зміни активності окисно-відновних ферментів відбувалися у макрофагах в різні фази репараційного процесу.

Висновки. Ми вважаємо, що такі відмінності можуть опосередковано вказувати на несвоєчасну зміну функціонального фенотипу макрофагів в ході відновних процесів у тканинах. Оскільки, макрофаги є «головним диригентом» міжклітинних взаємовідносин, припускається, що цей механізм може бути однією з причин неефективного загоєння ран при цукровому діабеті.

Ключові слова: клітинні реакції сполучної тканини, опікова травма, стійка некорегована гіперглікемія, фенотип макрофагів, ферменти тканинного окиснення. 
Natrus L.V., Verko N.P., Ryzhko I.N., Panova T.I., Osadchuk Yu.S.

\title{
ДИНАМИЧЕСКИЕ ИЗМЕНЕНИЯ ЭНЕРГЕТИЧЕСКОГО МЕТАБОЛИЗМА КЛЕТОК СОЕДИНИТЕЛЬНОЙ ТКАНИ КОЖИ БЕЛЫХ КРЫС В УСЛОВИЯХ ОЖОГОВОЙ ТРАВМЫ И ГИПЕРГЛИКЕМИИ
}

\author{
${ }^{1}$ Натрус Л.В., ${ }^{1}$ Верко Н.П., ${ }^{1}$ Рижкко И.М., ${ }^{2}$ Панова Т.И., ${ }^{2}$ Осадчук Ю.С. \\ ${ }^{1}$ Науково-исследовательский институт экспериментальной и клинической медицинь НМУ имени Богомольиа, \\ Киев, Украина \\ ${ }^{2}$ Национальний медичий университет имени Богомольца, Киев, Украина
}

\begin{abstract}
Актуальность. Макрофаги существуют в ране в нескольких фенотипических состояниях, и влияние этих клеток на межклеточную кооперацию каждого этапа тканевой репарации зависит от их конкретного фенотипа. В зависимости от микроокружения, они могут быстро менять свой функциональный фенотип с провоспалительного М1 на противовоспалительный М2, и наоборот. Однако влияние функционального фенотипа макрофагов на клеточный метаболизм не является односторонним, изменение особенностей метаболизма, прежде всего энергетического, также существенно влияет на фенотип клеток.

Целью работы было проанализировать активность окислительно-восстановительных ферментов нейтрофилов, макрофагов и фибробластов соединительной ткани кожи белых крыс, участвующих в процессах тканевого дыхания с локального термического повреждения при нарушении углеводного обмена в эксперименте для прогнозирования эффективности тканевой регенерации в ходе репарационного процесса.

Материалы и методы. Проведенные патоморфологические и гистохимические исследования динамики (3, 7, 14, 21 сутки) заживления ожоговой раны кожи белых половозрелых крыс-самцов линии Вистар массой 180-210 г без соматической патологии (контроль) $(\mathrm{n}=28)$ и при стойкой не корректированной стрептозотоцин- индуцированной гипергликемии (n=28). На криостатных срезах (10 мкм) проводили гистохимическое изучение активности оксидоредуктаз: сукцинатдегидрогеназы (СДГ), лактатдегидрогеназы (ЛДГ), НАДН-дегидрогеназы (НАДН-ДГ). Гистохимический показатель активности ферментов вычисляли полуколичественным методом.

Результаты. Исследование количественных изменений клеток в соединительнотканном регенерате и реакций энергетического метаболизма на фоне гипергликемии имеет ряд особенностей. Последовательность инфильтрации соединительной ткани различными видами лейкоцитов при репаративной регенерации после термической травмы проходила по классическому сценарию с количественным преобладанием клеток в группе животных без соматической патологии, указывает на уменьшение реактивности крови в условиях гликемии.

В динамике течения заживления изменение активности ЛДГ и НАДН-ДГ в макрофагах и фибробластах имело тенденцию к усилению на 7 и 14 сутки эксперимента и достоверно отличалось в ходе наблюдения показателей на 3 сутки (р <0,05).

Наиболее показательным для изучения динамики активности окислительно-восстановительных ферментов в клетках регенерата оказалось соотношение СДГ / ЛДГ. В сравнении данных контрольной группы животных и в условиях гипергликемии наиболее выражены и разнонаправленные изменения активности окислительно-восстановительных ферментов происходили в макрофагах в различные фазы репарационного процесса.

Выводы. Мы считаем, что такие различия могут косвенно указывать на несвоевременное изменение функционального фенотипа макрофагов в ходе восстановительных процессов в тканях. Поскольку макрофаги являются «главным дирижером» межклеточных взаимоотношений, предполагается, что этот механизм может быть одной из причин неэффективного заживления ран при сахарном диабете.
\end{abstract}

Ключевые слова: клеточные реакции соединительной ткани, ожоговая травма, стойкая некоррегированная гипергликемия, фенотип макрофагов, ферменты тканевого окисления. 